\title{
Assim na terra como no céu: reconsiderações sobre a poesia pura e a "ausência de mundo" na poética de Cecília Meireles
}

Idmar Boaventura Moreira ${ }^{\mathrm{i}}$

\begin{abstract}
RESUMO
Cecília Meireles afirmara, certa vez, que seu maior defeito seria uma "certa ausência de mundo". Alfredo Bosi vê essa ausência como virtude e a considera como chave para ler sua poesia. Mas a afirmação pode ser vista, também, como reveladora de um certo desconforto da poetisa, cuja obra equilibra-se na tensão entre comunicabilidade e incomunicabilidade, entre ausência e participação. $\mathrm{O}$ objetivo desse artigo é discutir o conceito de poésie pure e sua aplicação na lírica de Cecília Meireles, bem como a relação que a poesia ceciliana estabelece com o mundo e os acontecimentos à sua volta.
\end{abstract}

Palavras-chave: Cecília Meireles; Poesia pura; Ausência de mundo; Lírica e sociedade.

\begin{abstract}
Cecília Meireles had once stated that her biggest flaw would be a "certain absence of the world". Alfredo Bosi sees this absence as a virtue and considers it a key to reading her poetry. But the statement can also be seen as the revelation of a certain discomfort from the poet, whose work balances the tension between communicability and incommunicability, between absence and participation. The purpose of this article is to discuss the concept of poésie pure and its application in the lyric of Cecília Meireles, as well as the relationship that Cecilian poetry establishes with the world and the events around it.
\end{abstract}

Keywords: Cecília Meireles; Pure poetry; Absence of world; Lyric and society.

\footnotetext{
${ }^{\text {i }}$ Professor de Literatura - Departamento de Letras - UEFS.

ORCID: https://orcid.org/0000-0001-6253-0398 | idboaventura@ gmail.com
} 
Alfredo Bosi afirma que, em uma das muitas entrevistas que concedeu, Cecília Meireles confessou que seu maior defeito seria "uma certa ausência de mundo" - e que essa confissão seria um dos caminhos para entender sua poética, "uma pista para compreender a densidade e a estranha beleza da sua poesia" (2007, p. 13). O "mundo" que estaria ausente na poesia ceciliana seria, para o autor, "o fluxo das experiências vividas, tudo quanto foi visto, amado e sofrido" (2007, p. 13). O eu lírico da poesia ceciliana se afastaria da experiência vivida e conservaria, desse passado, apenas uma memória remota, quase espectral. Pura poesia, purgada o mais absolutamente possível das marcas do mundo à sua volta.

Quem primeiro apontou a afinidade de Cecília Meireles com a poesia pura e considerou essa a característica principal da poesia ceciliana foi Mário de Andrade. Para o poeta, "a verdadeira poesia", no seu "sentido interior e essencial", é "uma arte que, se joga necessariamente com as palavras que são o seu material, por outro lado prescinde daquilo para que a palavra foi criada: o raciocínio lógico, a concatenação de ideias [...]" (1972, p. 74); como "processo de conhecimento", a "poesia é uma intuição" que conduziria o sujeito a uma revelação de um "mundo interior", "irredutível, incomparável, inadaptável a leis gerais", afirma também que esse "sentimento profundo", só pôde ter "pela graça da poesia". E conclui que é essa a natureza “da força criadora de Cecília Meireles”. (1972, p. 74-75). Em outra ocasião, quando escreveu sobre Viagem (1939), disse não ver como traço fundamental da poesia ceciliana "nem sutilezas requintadas de pensamento, nem simplicidades popularescas" mas "vaguezas muito sensíveis, poderosamente intensas mas tênues, quase obscuras, em que a palavra se esgarça em seu sentido intelectual, readquirindo todo o seu poder sugestivo", e que “onde a poetisa se torna extraordinária e admirável é nos poemas que eu diria de poesia pura" (1972, p. 162; grifo nosso).

Muitos outros viram em Cecília Meireles a maior manifestação de poésie pure de nossa literatura. O português Jorge de Sena observa que "poucas expressões literárias haverá tão sempre identicamente resolvidas e tão pobres de significado, como a dos líricos puros, e Cecília seria uma delas", e, diz ainda, "no silêncio do lírico puro, reconhece-se a consciência de um lugar onde, como diz Cecília, nada mais precisa de explicação. E daqui resulta, necessariamente, a nadificação da poesia” (SENA, 1988, p. 19-20). Noutra ocasião, diz, da poesia de Cecília Meireles: 


\begin{abstract}
E tanto os temas como as metáforas devem ser compreendidos, não pelo que parecem ser, mas como pretextos que o poeta usa, um instrumental convencional (uma cifra pessoal), para fixar o que não é dizível, o que não é verbalizável, o que não é imaginável, por estar aquém ou além da forma e do signo. Disto é Cecília Meireles um dos mais altos exemplos na poesia de língua portuguesa.

$[\ldots]$

Uma poesia da confiança romântica e simbolista no poeta como vate (não para profetizar, mas para captar e dar expressão ao indizível) que, contraditoriamente, intelectualiza uma linguagem em cuja legitimidade não acredita. Uma criação obstinada de objectos estéticos que são infinitas variações sobre o silêncio, e a apresentação desses objectos como se fossem expressão. Uma extrema musicalidade que, semanticamente, não significa, já que essa música é o reflexo de uma altitude em que o calor humano não existe. Um abstraccionismo lírico que se recusa a visionar o mundo como significação, e que constantemente propõe uma linguagem pessoal como analogia para ele. (1988, p. 29, 31, grifos nossos)
\end{abstract}

A questão da poesia pura na obra de Cecília Meireles também é enfrentada por Leila Gouvêa (2008) em sua tese. A autora observa que, diferentemente do que ocorre com os poetas do Modernismo, há um reduzido aproveitamento, na lírica ceciliana, de temas e motivos prosaicos e cotidianos. O empírico e o concreto cedem lugar, nessa lírica, para a memória e o abstrato, a partir de um processo de transfiguração do real, "por via da indagação metafísica" ou "da mediação simbólica, de deformação onírica ou da metamorfose do banal no maravilhoso, no sublime ou no sobrenatural" (2008, p. 6970) - o que põe em evidência o substrato do surrealismo nessa lírica, observável também na indeterminação do espaço: o lugar de onde o eu lírico fala é ideal e imaginário, ou ainda memorialístico e fantasmagórico. A "transfiguração do sensível" na lírica ceciliana, diz Leila Gouvêa, "é tão forte que abstrai quase todo resquício da experiência para [...] deixar apenas o irredutível” (2008, p. 92) - lição que Cecília Meireles teria aprendido dos românticos alemães e de Mallarmé.

Há algumas considerações importantes a fazer aqui: pode parecer, à primeira vista, que Mário de Andrade, Jorge de Sena e Leila Gouvêa tratem, essencialmente, da mesma característica da poesia ceciliana: o cultivo da poesia pura. Só à primeira vista, entretanto; a questão está na forma como cada um compreende o termo.

Em termos gerais, poésie pure é aquela em que, pelo trabalho de depuração, a linguagem alcança um estado de autonomia em relação ao discurso; a linguagem mesma ganha o status de realidade absoluta. O termo deriva do anseio simbolista de reduzir ao máximo o valor semântico da palavra e explorar suas propriedades fonéticas para atingir 
na poesia a condição de música. Essa busca se dá porque os simbolistas desconfiaram da ideia de uma relação transparente entre as palavras e as coisas. Tal posição será radicalizada por Mallarmé - que recusa o pacto de referência, negando a correspondência entre a linguagem e o mundo; diante da impossibilidade de transpor o mundo, a linguagem, em Mallarmé, reivindica sua autonomia em relação a ele. Friedrich (1978) comenta que a poesia pura de Mallarmé quer "prescindir de matérias da experiência cotidiana, de conteúdos didáticos ou outros utilitários, de verdades práticas, de sentimentos corriqueiros, da embriaguez do coração" para, purificada desses elementos, tornar-se "livre para deixar dominar a magia linguística" (1978, p. 136-137). Paul Valéry - herdeiro de Mallarmé, em quem a teorização dessa poesia alcançou seu auge -, em um texto de 1920 (prefácio de um livro do poeta Lucien Fabre), argumenta que a poesia deve se distanciar radicalmente da prosa, a fim de alcançar a pureza. "A poesia pura seria a realização do poema purgado das formas prosaicas e narrativas, purgado do récit, poema que assim ficaria reduzido, simplificado a um estado puramente poético; a poesia pura seria o estado de pura poesia" (PIMENTEL, 2011, $s / p$ ). Valéry entende que tal grau de pureza é impossível de alcançar, mas que deve ser esse o alvo de todo poeta. "A poesia pura nada mais é do que um limite situado no infinito, um ideal do poder de beleza da linguagem... Mas é a direção que importa, a tendência em direção à obra pura. É importante saber que toda poesia se orienta em direção a alguma poesia absoluta" (VALÉRY, 1997, pp. 676-677; apud PIMENTEL, 2011, s/p). Assim, a pureza em Mallarmé e Valéry é um conceito que se poderia chamar de 'mineral': a poesia pura é uma rara pedra preciosa, purificada de quaisquer impurezas. Encontrá-la não seria resultado da intuição, do acaso ou da inspiração, mas sim do intenso trabalho (racional, evidentemente) de mineração do poeta.

Há, porém, outra concepção de poesia pura, diversa daquela de Mallarmé e Valéry, de grande repercussão no Brasil, que gozou de grande prestígio entre os espiritualistas de Festa e exerceu forte influência na obra de poetas como Augusto Frederico Schimidt e Jorge de Lima. O abade Henry Bremond publica, em 1925, um texto intitulado "La poesie pure". Embora faça referência, já no primeiro parágrafo, a "les modernes théoriciens de la poésie pure, Edgar Poe, Baudelaire, Mallarmé, M. Paul Valéry", apresenta uma ideia de poesia pura diversa daquela que encontramos nos poetas citados (mais particularmente, nos dois últimos). Como Valéry, ele entende que 
um poema de pura poesia é uma impossibilidade; entende também que há poesia pura (cercada de impurezas) em todo poema - condição sine qua non para defini-lo como tal. Mas Brémond (1926, p. 16-27) dá à questão contornos metafísicos. Para ele, as palavras comuns, quando colocadas em seu lugar no poema, vibram e dão acesso à intuição poética, uma experiência inacessível à consciência: "Il y a encore dans la poésie de certaines choses ineffables et qu'on ne peut expliquer. Ces choses en sont comme les mystéres [...] Tout poème doit son cacactère proprement poétique à la présence, au dayonnement, à l'action transformate et unifiante d'une réalite mystérieuse que nous appelons poésie pure”). Essa "realidade misteriosa" não estaria no campo da razão; “reduire la poésie aux demárches de la connaissance rationnelle, du discours, c'est aller contre la nature même, c'est vouloir un cercle carré”; a compreensão do poema prescinde mesmo da razão, já que a poesia se deixa compreender pelo espírito, a partir da intuição ("intuition infaillible") : "pour lire un poème comme il faut, je veux dire poétiquement, il ne suffit pas, et, d'ailleurs, il n'est pas tourjours nécessaire d'en saisir le sens"; é a vitória da poesia sobre a razão ("victoire du pur sur l'impur, de la poésie sur la raison” - 1926, p. 19).

Voltemos então a Cecília Meireles. Parece-nos que, quando se fala na 'poesia pura' da autora, ora se fala a partir da noção mallarmiana, ora da de Bremond. Quando Jorge de Sena fala do "abstraccionismo lírico" e Leila Gouvêa da "transfiguração do real" na poesia ceciliana, é Mallarmé sua referência imediata. Não parece ser o caso, entretanto, de Mário de Andrade, que realça o valor da "intuição" e de uma "revelação interior" que só se torna possível a partir da experiência poética - evidentemente, a referência é Bremond. O que diria a própria Cecília Meireles?

Até onde se sabe, Cecília Meireles não teorizou sobre a poesia pura. Mas é interessante observar como uma outra poetisa, sua contemporânea, o fez. Trata-se de Henriqueta Lisboa. No ensaio "Poesia pura", argumenta que a expressão pode provocar confusão, já que ganhou diferentes matizes. Mas se posiciona a favor do sentido que lhe dá Bremond. "Puro", diz ela (a partir de uma citação de Robert de Souza, partidário do abade, cujo texto "Un débat sur la poésie" foi publicado em anexo ao livro de Bremond),

não deve ser compreendido no sentido químico de água destilada, da qual foram eliminados os elementos vivos para alcançar a perfeita pureza da 
substância mineral; senão no sentido biológico de "pursang", quando o ser manifesta os caracteres mais distintivos, mais de acordo com suas origens, as virtudes mais completas e mais raras de sua natureza. (LISBOA, 1955, p. 80)

É justamente o oposto do que pensava Valéry. Henriqueta diz ainda que, "libertada das formas elementares da paixão (que não são formas criadoras), do juízo afeito a discernir o real do irreal (impróprio à beatitude poética)", a poesia atinge "seu mais elevado estágio, um mundo de perspectivas extraordinárias, onde impera a intuição", bem como alerta para "os perigos do hermetismo, da desumanização, do silêncio total" que a "pureza química" de Mallarmé e de Valéry pode representar. (1980, p. 80, 81). Em um outro texto (“Convívio poético”), deixa claro que, a seu ver, não é esse o caso da poesia de Cecília Meireles. "Longe de mostrar-se alheia à condição humana" diz ela, "Cecília costuma superar essa condição com nobreza e discrição, a que não deixam de associar-se leves tons de ironia” (1955, p. 180).

Cecília Meireles talvez concordasse (em parte, pelo menos) com Henriqueta Lisboa. Em entrevista concedida a Pedro Bloch, publicada inicialmente na revista Manchete ( $\mathrm{n}^{\mathrm{o}}$. 630, 16/05/1964), confessa: "Você sabe que eu tenho muito medo da literatura que só é literatura e não tenta comunicar?" (BLOCH, 1989, p. 32). Sua afirmação, de que seu maior defeito é "certa ausência de mundo" (o pronome indefinido deve ser realçado), que Alfredo Bosi vê como virtude e considera como chave para ler sua poesia, pode ser vista, também, de outro modo - ela revela um desconforto da poetisa, cuja obra equilibra-se na tensão entre comunicabilidade e incomunicabilidade, entre ausência e participação. Essa ambiguidade se apresenta em toda a sua obra; ao mesmo tempo em que se define como "pastora de nuvens" " no poema "Destino" (2001, p. v. 1, 292), lamenta, no poema "Canção da tarde no campo" (2001, v.1, p. 398): “de tanto olhar para longe / não vejo o que passa perto". Ao mesmo tempo em que declara, em Solombra: "quem me vê não me vê, que estou fora do mundo" (2001, v.2, p. 1264), diz, também lá: "há uma força que prende / o instante de minha alma aos instantes da terra, / como se os mundos dependessem desse encontro" (2001, v. 2, p. 1272). Seu procedimento criativo, evidenciado na busca de perfeição formal e da musicalidade, e mesmo na sua percepção dos limites da linguagem (“As palavras estão com seus pulsos imóveis", canta em Solombra - 2001, v. 2, p. 1272), revela a influência de Mallarmé e Valéry; seu desejo de comunicar a aproxima de Bremond. 
Uma característica fundamental do nosso Modernismo - a busca da afirmação de uma identidade nacional - está ausente da poesia ceciliana, e o mesmo se pode dizer de uma preocupação com o cotidiano, o anedótico e o prosaico, tão valorizados pelos nossos modernistas. Sobre o efeito disso na apreciação crítica da poesia de Cecília Meireles, Lucia Helena comenta:

\begin{abstract}
Desde os primeiros livros se evidencia a falta de afinidade de sua poesia com a dos modernistas heroicos, liderados pelo "biscoito fino" oswaldiano e a pauliceia desvairada e melancólica de Mário. Se uma tal dissonância não impediu que fosse presença admirada, teve o efeito de imprimir-lhe o clichê de poeta do etéreo, afastada do drama coletivo e das mudanças com que se defrontava o mundo entre as duas grandes guerras. Para uns, isto comprovava a qualidade de um lirismo "autêntico", porque baseado na fusão do sujeito e do objeto, como na leitura que do fenômeno lírico faz Emil Steiger. Para outros, significava lançar-lhe a pecha de alienação. (2004, p. 209)
\end{abstract}

Essa "pecha" parece ter vingado; "Cecília ficou, no modernismo, como a contemplativa, a evanescente, a desligada" (MARQUES, 1972, p. 53). E essa leitura da poesia de Cecília Meireles criou profundas raízes. Veja-se, por exemplo, o que acontece no acurado estudo que Valéria Lamego (1996) faz da produção jornalística de Cecília Meireles dos anos 1930. Nele, apresenta uma Cecília Meireles como "uma jornalista liberal, defensora incansável das liberdades individuais, da paz, da instauração de uma república democrática, bem diferente daquela regida pelo populismo autoritário do regime [a ditadura de Getúlio Vargas] que se descortinava" (1996, p. 19). Essa “jornalista liberal" era "crítica ferrenha das atitudes autoritárias de Vargas", a quem se referia como "Senhor ditador" (1996, p. 20-21), e não poupava críticas nem à Igreja Católica (que se opunha aos ideais da Escola Nova, defendidos por Cecília) nem ao nacionalismo desenfreado daqueles anos. Valéria Lamego diz ainda que:

A política era a grande aventura da poetisa, que se entregava ao "horror" do
jornalismo com o firme propósito de fazer valer na página impressa suas
reflexões sobre os acontecimentos da Europa, como a ascensão nazi-fascista,
e do Brasil, como a Constituinte; enfim, sobre todo o movimento de
transformação que o mundo iria vivenciar naquela década. $(1996$, p. 60$)$

Tendo reconstituído essa importante faceta da atividade intelectual de Cecília Meireles, é com certa perplexidade que Valéria Lamego afirma que "é impossível que a jornalista irônica e a poeta lírica fossem duas pessoas e não permitissem que a farpa da militância, de uma, maculasse a lira da poesia 'cristalina' da outra” (1996, p. 116). Ela mesma, porém, não leva em conta essa "impossibilidade", e separa a poetisa Cecília 
Meireles da "outra Cecília", como repete várias vezes em seu texto. Sua conclusão é de que:

\begin{abstract}
Para o mundo "livresco", [...] Cecília Meireles construiu uma personalidade altamente estetizada, cuja marca maior e motivo se encontram no verso: "não sou alegre nem triste, sou poeta" [...]. Para representar essa personalidade, que aparentemente se manteve longe do debate político diário, foram escolhidas fotos de uma moça com "olhos glaucos", beatificados, que quase sempre ilustraram as contracapas das edições de seus livros. [...]. A poetisa construiu sua imagem do princípio ao fim. (1996, p. 60)
\end{abstract}

Lucia Helena (2004, p. 211) discorda da conclusão de Valéria Lamego. Ela considera equivocadas tanto a crítica que, no passado, "lacrou, num reducionismo ingênuo, aspectos instigantes da poesia de Cecília Meireles, rotulando-a de solitária e intimista", quanto a conclusão de Lamego, que acaba por encerrar Cecília "num outro ponto cego, no qual a dicotomia-base se converte na oposição entre a jornalista engajada e a poeta dos estados d'alma". Mas a leitura atenta da poesia de Cecília Meireles desfaz esse ciclo vicioso e deixa ver de que maneiras a poetisa equilibra o exercício da poesia pura com a participação, atenta, aos acontecimentos do mundo à sua volta. Tais acontecimentos recebem de Cecília Meireles um trabalho de depuração; expurgado o poema “da cópia servil das coisas, da lógica prosaica, da eloquência oratória, anedótico, do didático" - o que caracteriza a poesia pura, conforme a vê Henriqueta Lisboa (1955, p. 81) -, fica um certo 'sentimento de mundo', que é a matéria-prima de sua poesia. $\mathrm{O}$ circunstancial é transitório, e Cecília Meireles quer o eterno. É, portanto, incorreto dizer que a poesia de Cecília Meireles é alheada do mundo; uma leitura mais atenta pode demonstrar que o mundo está lá, esteticamente reconstruído (ou, para usar as palavras de Cecília, "reinventado").

A título de exemplo, observemos, mesmo panoramicamente, a obra que deu a Cecília Meireles sua maioridade poética, Viagem (1939). Todos os grandes temas cecilianos estão ali: a busca do eterno instante e as relações entre o transitório e o eterno, a depuração poética do sentimento da morte, a inconsistência do eu e suas relações com o mundo objetivo, a busca de um outro indefinível, e, principalmente, a poesia como revelação - tema que permeia toda a obra -, entre outros. À primeira vista, poesia pura, alheada do mundo à sua volta. Mas não haveria, no sentimento de transitoriedade, certamente presente na obra, um reflexo daqueles anos de profundas mudanças e incertezas políticas, no Brasil e no mundo? Cecília Meireles assistiu, nos 
anos 1930, ao surgimento do nazismo de Hitler na Alemanha, do fascismo do general Franco na Espanha e do regime totalitarista de Salazar em Portugal; no Brasil, aqueles também foram anos de muita instabilidade política, que culmina num regime ditatorial instituído por Getúlio Vargas em 1937, e Cecília Meireles evidentemente sentiu seus efeitos $^{2}$. Sua poesia não estava isenta de tudo isso. Dois poemas de Viagem nos parecem bem sugestivos no que diz respeito àquele 'sentimento de mundo' de que falamos acima: "Feitiçaria" (2001, v. 1, p. 297) e "Marcha" (2001, v. 1, p. 297):

\author{
Feitiçaria \\ Não tinha havido nem pássaros nem flores \\ o ano inteiro. \\ Nem guerras, nem aulas, nem missas, nem viagens \\ e nem barca e nem marinheiro. \\ Nem indústria ou comércio, nem jornal nem rádio, \\ o ano inteiro! \\ Nem cartas nem modas. Tudo quanto havia \\ era o feitiço de um feiticeiro \\ que toldava o mundo e a melancolia. \\ Chegaram agora pássaros e flores, \\ e de novo guerras, aulas, missas, viagens, \\ e marinheiros com remos e barcas \\ vêm saindo do horizonte. \\ Brotam de novo antigas imagens \\ das coleções de fotografias... \\ - moços com roupas de Caronte \\ e meninas iguais às Parcas. \\ Por isso é que se tem saudade \\ do tempo da feitiçaria.
}

"Feitiçaria" expressa uma concepção cíclica do tempo. O "tempo da feitiçaria" substitui um tempo anterior, quando havia "pássaros e flores", "guerras, aulas, missas, viagens", "indústria, comércio, jornal, rádio"; agora, nada disso existe. Na verdade, é como se o "tempo da feitiçaria" fosse uma suspensão do tempo: "tudo quanto havia / era o feitiço de um feiticeiro / que toldava o mundo e a melancolia". Toldado, encoberto, envolvido pelo feitiço, o mundo da natureza e o mundo da cultura não existiam, ou existiam apenas em estado de suspensão. Retira-se o toldo, desfaz-se o feitiço, e o mundo torna a girar, chegam "pássaros e flores", como a indicar o movimento da terra e os ciclos das estações, "e de novo guerras, aulas, missas, viagens, / e marinheiros com 
remos e barcas", como a indicar o mundo das coisas humanas. E "brotam de novo antigas imagens / das coleções de fotografias": "moços com roupas de Caronte / e meninas iguais às Parcas". A referência às Parcas - Clotos, Láquesis e Átropos, deusas da mitologia grega, que tinham a função de tecer, fiar e cortar o fio da vida - reforça a ideia de retorno do movimento fatal do tempo, que o feitiço tinha posto em suspensão, imagem também reforçada pela referência a Caronte, o barqueiro do Hades. A última estrofe expressa o desejo de retorno do "tempo da feitiçaria", o que indica, portanto, a rejeição daquele tempo corrente. Como não pensar nesse tempo de "guerras", "marinheiros", das "Parcas" e de "Caronte", e de "jornais e rádios" a transmitirem o 'espetáculo do mundo', como expressão do sentimento daqueles anos da década de 1930? O poema seguinte, "Marcha" (2001, v. 1, p. 297), é também representativo nesse aspecto:

Marcha

As ordens da madrugada romperam por sobre os montes: nosso caminho se alarga sem campos verdes nem fontes. Apenas o sol redondo e alguma esmola de vento quebraram as formas do sono com a ideia de movimento.

Vamos a passo e de longe, entre nós dois anda o mundo, com alguns vivos pela tona, com alguns mortos pelo fundo. As aves trazem mentiras de países sem sofrimento. Por mais que alargue as pupilas, mais minha dúvida aumento.

Também não pretendo nada senão ir andando à toa como um número que se arma e em seguida se esboroa - e cair no mesmo poço de inércia e de esquecimento, onde o fim do tempo soma pedras, águas, pensamento.

Gosto da minha palavra pelo sabor que lhe deste: mesmo quando é linda, amarga como qualquer fruto agreste. Mesmo assim amarga, é tudo que tenho, entre o sol e o vento: 


\author{
meu vestido, minha música, \\ meu sonho e meu alimento. \\ Quando penso no teu rosto, \\ fecho os olhos de saudade; \\ tenho visto muita coisa, \\ menos a felicidade. \\ Soltam-se os meus dedos tristes \\ dos sonhos claros que invento. \\ Nem aquilo que imagino \\ já me dá contentamento. \\ Como tudo sempre acaba, \\ oxalá seja bem cedo! \\ A esperança que falava \\ tem lábios brancos de medo. \\ O horizonte corta a vida, \\ isento de tudo, isento... \\ Não há lágrima nem grito: \\ apenas consentimento.
}

O poema, construído em redondilha maior, lembra o ritmo dos poemas de cordel. E nos lembra, na primeira estrofe, a marcha dos retirantes nordestinos que fogem da seca. Atualizando a imagem até nossos dias, podemos ver, nela, o drama dos milhares de refugiados que fogem, diariamente, da guerra e da fome. Pode nos fazer lembrar também da marcha de soldados no campo de batalha, seguindo "as ordens da madrugada". Em qualquer um dos casos, a imagem, "sem campos verdes nem fontes", é de desolação - reforçada pelo sol redondo, e a quase ausência de vento, do qual só se tem "alguma esmola". Quem descreve a paisagem é um eu lírico que, se dirigindo a alguém, relata o que ele e os com ele encontram no caminho. O poema inteiro lembra, assim, uma missiva. Uma carta a um amor distante.

A segunda estrofe amplia nosso escopo de visão, e reforça a imagem da guerra: entre o eu lírico e seu interlocutor "anda o mundo", coberto de "vivos" e "mortos". E as notícias que chegam, trazidas pelas aves, de "países sem sofrimento", não convencem esse eu lírico cercado de desolação, que, por mais que tente olhar mais longe, mais delas duvida. De qualquer forma, continua a caminhada, como nos diz a terceira estrofe. Sem pretensão ou esperança alguma, segue "andando à toa". Nem é como alguém que segue: é "como um número que se arma / e em seguida se esboroa"; armar tem aqui um sentido ambíguo; pode ser visto como montar, erigir, mas também um número "que se arma" como um soldado na batalha, do qual pouco se sabe quando sucumbe e cai no poço "de inércia e de esquecimento", onde o tempo inexoravelmente lança tudo. O que resta ao 
eu lírico é sua palavra, "linda", mas "amarga", que é "tudo que tem" "entre o sol e o vento", como lemos na quarta estrofe. O tom de desesperança que percorre todo o poema se mantém nas duas estrofes finais. O eu lírico precisa fechar os olhos para "ver" o rosto de seu interlocutor e se esquivar do muito que vê, e mesmo o que inventa ou imagina pouco o consola. Naqueles campos abrasados, em que até mesmo a esperança "tem lábios brancos de medo", o que se pode esperar é que, "como tudo sempre acaba", cedo acabe aquela marcha.

Mar absoluto foi publicado em 1945. No poema "Compromisso", uma voz feminina revela uma "sobrenatural obrigação" que tem com os mortos, bem como uma compreensão do papel da poesia diante do horror. "Vivo por homens e mulheres / de outras idades, de outros lugares, com outras falas”, diz ela. Sua obrigação é viver, para que os "que se foram, / ou cedo ou irrealizados", vivam por meio dela. Para realizar a tarefa, diz, precisa multiplicar-se em muitos 'eus': “esta sou eu: a inúmera. / Que tem que ser pagã como as árvores / e, como um druida, mística” (2001, v. 1, p. 461). Diz ainda, sobre seu compromisso:

\author{
Fora do planeta e do firmamento, \\ bússola enamorada da eternidade, \\ um sentimento lancinante de horizontes, \\ um poder de abraçar, de envolver \\ as coisas sofredoras, \\ e levá-las nos ombros, como os anhos e as cruzes.
}

Essa comunhão com os mortos, "povo" que conduz e a quem "se entrega", esse sentimento que lhe permite "envolver / as coisas sofredoras, / e levá-las nos ombros", pode produzir felicidade mesmo em "lugares sem sol nem lua", mesmo naqueles tempos tenebrosos. Com efeito, Mar absoluto é densamente povoado por esses mortos. São inúmeras as referências, diretas e indiretas, à guerra e a seus efeitos, muitas delas já evidenciadas no título dos poemas: "Lamento da noiva do soldado", "Balada do soldado Batista", "Lamento do oficial por seu cavalo morto", "Guerra", etc. Nesse último, o eu lírico expressa profunda indignação diante do horror da guerra e da indiferença dos homens (2001, v. 1, p. 541):

\title{
Guerra
}

Tanto é o sangue 
que os rios desistem de seu ritmo,

e o oceano delira

e rejeita as espumas vermelhas.

Tanto é o sangue

que até a lua se levanta horrível,

e erra nos lugares serenos,

sonâmbula de auréolas rubras,

com o fogo do inferno em suas madeixas.

Tanta é a morte

que nem os rostos se conhecem, lado a lado,

e os pedaços de corpos estão por ali como tábuas sem uso.

Oh, os dedos com alianças perdidos na lama...

Os olhos que já não pestanejam com a poeira...

As bocas de recados perdidos...

O coração dado aos vermes, dentro dos densos uniformes...

Tanta é a morte

que só as almas formariam colunas,

as almas desprendidas... - e alcançariam as estrelas.

E as máquinas de entranhas abertas,

e os cadáveres ainda armados,

e a terra com suas flores ardendo,

e os rios espavoridos como tigres, com suas máculas,

e este mar desvairado de incêndios e náufragos,

e a lua alucinada de seu testemunho,

e nós e vós, imunes,

chorando, apenas, sobre fotografias

- tudo é um natural armar e desarmar de andaimes

entre tempos vagarosos,

sonhando arquiteturas.

Os rios, o oceano e a lua testemunham, com os homens, a matança da guerra. "Tanto é o sangue", rezam o primeiro e o quinto versos", "tanta é a morte", dizem o décimo e o décimo sétimo - a repetição enfatiza a dimensão e a gravidade da violência, assim como as palavras "vermelhas" e "rubras" remetem ao sangue. Há ainda, no poema, outras imagens com forte carga de realismo e de inspiração cubista, da terceira à quinta estrofes: "pedaços de corpos estão por ali como tábuas sem uso", “dedos com alianças perdidos na lama" ou "coração dado aos vermes". A partir dessas imagens, o eu lírico compõe um painel do campo de batalha, e pretende, a partir dele, comover seu interlocutor, o que é reforçado, ainda, na sexta estrofe, cujos primeiros seis versos, iniciados com a conjunção aditiva " $e$ ", enumeram os efeitos da guerra, bem como a reação da terra, do oceano, dos rios e da lua, elementos naturais humanizados no 
poema. Estes são profundamente afetados pela guerra: a terra "arde", os rios, "espavoridos", “desistem do seu ritmo"; o mar, "desvairado de incêndios e náufragos", "delira / e rejeita as espumas vermelhas", e a lua "alucinada", "se levanta horrível / e erra nos lugares serenos". Em contraste, é bem diferente a reação de homens e mulheres; no sétimo verso da sexta estrofe a conjunção "e" funciona não como conjunção aditiva, mas como adversativa: "e nós e vós, imunes / chorando, apenas, sobre fotografias" [grifo nosso]. Para aqueles que assistiam à guerra, de longe, a matança era apenas algo lamentável, mas que não lhes afetava diretamente; quando muito, arrancava alguma lágrima, o que, na perspectiva do eu lírico, era muito pouco. $\mathrm{O}$ poema, a partir da ênfase na retratação dos horrores da guerra, bem como do contraste entre a reação dos elementos naturais e a reação das pessoas, produz um apelo, ou mesmo uma exigência de reação da humanidade.

No poema "Os homens gloriosos” (2001, v. 1, p. 545), Cecília Meireles parece contrapor aquela imagem dela mesma como "pastora de nuvens" ausente do mundo, com a de alguém profundamente afetado pelos acontecimentos à sua volta:

Os homens gloriosos

Sentei-me sem perguntas à beira da terra, e ouvi narrarem-se casualmente os que passavam.

Tenho a garganta amarga e os olhos doloridos: deixai-me esquecer o tempo, inclinar nas mãos a testa desencantada, e de mim mesma desaparecer - que o clamor dos homens gloriosos cortou-me o coração de lado a lado.

Pois era um clamor de espadas bravias, de espadas enlouquecidas e sem relâmpagos, ah, sem relâmpagos... pegajosas de lodo e sangue denso.

Como ficaram meus dias, e as flores claras que pensava! Nuvens brandas, construindo mundos, como se apagaram de repente! Ah, o clamor dos homens gloriosos atravessando ebriamente os mapas!

Antes o murmúrio da dor, esse murmúrio triste e simples de lágrima interminável, com sua centelha ardente e eterna.

Senhor da Vida, levai-me para longe! Quero retroceder aos aléns de mim mesma! Converter-me em animal tranquilo, em planta incomunicável, 


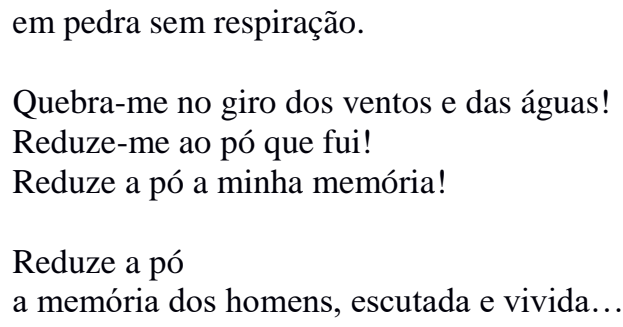

Enquanto em "Guerra" o eu lírico se refere aos que assistem imunes ao espetáculo da guerra, o poema "Os homens gloriosos" trata daqueles que a fazem. Escutar o "clamor" dos "homens gloriosos" provoca, no eu lírico, desencanto tal que deseja “desaparecer”. Que clamor é esse? "Um clamor de espadas bravias, / de espadas enlouquecidas e sem relâmpagos, / ah, sem relâmpagos... / pegajosas de lodo e sangue denso". A imagem de grandes guerreiros ou anjos e deuses empunhando espadas relampejantes ou flamejantes é comum em muitas culturas. À porta do Jardim do Éden, Javé colocou dois anjos com espadas flamejantes, para impedir a entrada no paraíso; Acala, o Senhor da Sabedoria - uma deidade budista - é representado com uma espada flamejante; Yansã, a orixá guerreira do candomblé, é senhora dos relâmpagos e tempestades, e comumente representada empunhando uma espada. Mas não há nada de elevado ou divino naqueles homens que fazem a guerra, "atravessando ebriamente os mapas"; suas espadas estão "pegajosas de lodo e sangue denso" - a imagem é repulsiva - e atestam como é falsa a sua glória. Ela significa, para o eu lírico, um desencantamento do mundo, daquele mundo onde a poetisa se posicionaria como "pastora de nuvens": "Como ficaram meus dias, e as flores clara que pensava! / Nuvens brandas, construindo mundos, / como se apagaram de repente!"”. O eu lírico, sem suportar o mundo da guerra, chega a desejar uma nadificação, expressa a partir de uma gradação descendente: quer ser convertida em "animal tranquilo", em "planta incomunicável", em "pedra sem respiração e, finalmente", ser "reduzida a pó". E mais: que seja reduzida a pó "a memória dos homens, escutada e vivida". Mas vale ressaltar: as "nuvens brandas" "se apagaram", e é sentado "à beira da terra" escutando "os que passavam" que o eu lírico se encontra. Não era possível, naquele momento, ausentar-se do mundo.

Os poemas de guerra também estão em Retrato natural, publicado em 1949. São dele os poemas "O cavalo morto" e "Declaração do amor em tempos de guerra"; em 1955, Cecília Meireles publica Pistóia, cemitério militar brasileiro, obra composta 
de um único poema, que trata dos soldados brasileiros mortos na Segunda Guerra a partir da sua perspectiva humanista e pacifista; e dois anos antes a poetisa já havia publicado seu Romanceiro da Inconfidência, um longo poema épico acerca da conjuração mineira. A dicção da obra - o mais importante poema épico moderno da literatura brasileira - é lírica e existencialista, mas sem se desligar da realidade empírica, muito pelo contrário: sua reflexão sobre as relações de poder, a ganância, a corrupção, a violência, enfim, sobre as relações entre os menos favorecidos, os 'vencidos' e os 'vencedores' donos do poder, daquele período de nossa história, reflete sua percepção do mundo em que vivia.

Do mesmo modo, a poesia de Cecília Meireles não está alheia a questões de gênero. No conhecido ensaio "Literatura e mulher: essa palavra de luxo" (2016), Ana Cristina Cesar critica a leitura tradicional da poesia de Cecília Meireles e de Henriqueta Lisboa, que não ultrapassaria o senso comum sobre o poético e o feminino, para o qual a poesia - e mais especificamente a poesia feita por mulheres - é a busca do belo e da natureza, e a busca do "inatingível, inefável, profundo" (2016, p. 157). Dois posicionamentos da crítica são condenados pela autora: aquele que vê "na delicadeza e na nobreza da poesia [das duas autoras] algo de feminino" e aquele que "silencia qualquer referência ao fato de que se trata de mulheres, como se falar isso fosse irrelevante ante a realidade maior da Poesia" (2017, p. 258). O irônico é que, apesar da argúcia com que lê a crítica tradicional sobre a poesia feminina, Ana Cristina Cesar acaba repetindo o que diz a mesma crítica em relação à poesia de Cecília Meireles: “Cecília levita, como um puro espírito... Por isso ela se move, 'viaja', sonha com navios, com nuvens, com coisas errantes e etéreas, móveis e espectrais, transformando em poesia pura essa caminhada (2016, p. 258)" - reforça, portanto, o discurso que reduz a poesia ceciliana à poesia pura. Ana Cristina Cesar considera ainda que Cecília "não tem nenhuma intervenção renovadora na produção poética brasileira", e que tanto ela quanto Henriqueta Lisboa "nunca inquietaram ninguém" e "jamais se colocaram como mulheres. Marcaram não presença de mulher, mas a dicção que se deve ter, a nobreza e o lirismo e o pudor que devem caracterizar a escrita de mulher" (2016, p. 261). O resultado disso seria que, como principal nome feminino na poesia brasileira, Cecília Meireles acaba por "definir o lugar onde a mulher começa a se localizar em poesia. Cecília abre alas: alas da dicção nobre, do bem falar, do lirismo distinto, da delicada 
perfeição. Quando as mulheres começam a produzir literatura, é nessa via que se aliam" (2016, p. 260).

Talvez o maior equívoco de Ana Cristina Cesar seja uma espécie de anacronismo, que consistiu em esperar de Cecília Meireles um posicionamento diante das questões femininas que só seria possível décadas depois de Cecília. Vale a pena observar que o exemplo que Ana Cristina Cesar apresenta de uma "outra via, de uma outra produção alternativa de mulher em relação à via Cecília/Henriqueta" (2016, p. 263) seja Adélia Prado, que, diz a autora, "supera a feminização do universo imagético pela feminização temática” (2016, p. 263). Não fosse esse anacronismo, Ana Cristina Cesar talvez não tivesse repetido a mesma leitura reducionista que condenava, e tivesse podido observar de que formas Cecília Meireles teria tratado das questões relativas à mulher. Teria visto que, assim como na poesia de Adélia Prado, na poesia ceciliana o feminino também é tematizado. Já em seu primeiro livro, Espectros (publicado em 1919, quando a poetisa contava, como já dissemos, apenas dezoito anos de vida), personagens femininas históricas ganham relevo, sendo temas da maioria dos poemas: Cleópatra (no poema "Antônio e Cleópatra", 2001, v. 1, p. 19), "Herodíada" (2001, v. 1, p. 19), "Judite" (2001, v. 1, p. 20), Dalila (“Sansão e Dalila", 2001, v. 1, p. 21), "Joana d'Arc" (2001, v. 1, p. 21), "Maria Antonieta" (2001, v. 1, p. 22). Ainda que esses poemas não problematizem diretamente questões relativas ao lugar da mulher na sociedade na segunda década do século XX, quando foram escritos e publicados - uma época de efervescência dos movimentos feministas na Europa e nas Américas -, não devemos deixar de perceber que aquelas personagens femininas tematizadas por Cecília Meireles em Espectros têm em comum entre si o fato de serem mulheres fortes, que, cada uma a sua maneira, influenciou decisivamente os acontecimentos à sua volta. Em Viagem, livro que, à primeira vista, não parece abordar o universo feminino, aparece o poema "Retrato" (2001, v. 1, p. 232), que inaugura uma temática importante na poesia ceciliana: a da mulher diante do espelho (que aparecerá, por exemplo, em Vaga música (1942), nos poemas "Epigrama do espelho infiel" (2001, v. 1, p. 340), "Retrato falante" (2001, v. 1, p. 375) e "Rosto perdido" (2001, v. 1, p. 409), em Mar absoluto (1949) nos poemas “Auto-retrato" (2001, v. 1, p. 456) e "Mulher ao espelho" e, em Retrato natural (1949), nos poemas "Fui mirar-me" (2001, v. 1, p. 630) e "Retrato de uma criança com uma flor na mão" (2001, v. 1, p. 658), entre outros); é recorrente, nesses poemas, a 
figura de um eu lírico feminino que, diante do espelho, questiona sua própria identidade, em virtude do seu fracasso perante uma exigência de juventude e beleza que são, por sua vez, efêmeras - e não é essa, ainda hoje, em nossa sociedade cada vez mais pautada na aparência, importante questão tanto para as mulheres como para os homens?

Dois poemas exemplares da "feminização temática" na poesia de Cecília Meireles e de seu compromisso com a emancipação feminina são a "Balada das dez bailarinas do cassino" (2001, v. 1, p. 617), publicado em Retrato natural (1949) e “Prisão", poema de 1956 (2001, v. 2, p. 1759):

Balada das dez bailarinas do cassino

Dez bailarinas deslizam por um chão de espelho. Têm corpos egípcios com placas douradas, pálpebras azuis e dedos vermelhos. Levantam véus brancos, de ingênuos aromas, e dobram amarelos joelhos.

Andam as dez bailarinas sem voz, em redor das mesas.

Há mãos sobre facas, dentes sobre flores e os charutos toldam as luzes acesas. Entre a música e a dança escorre uma sedosa escada de vileza.

As dez bailarinas avançam como gafanhotos perdidos. Avançam, recuam, na sala compacta, empurrando olhares e arranhando o ruído. Tão nuas se sentem que já vão cobertas de imaginários, chorosos vestidos.

As dez bailarinas escondem nos cílios verdes as pupilas. Em seus quadris fosforescentes, passa uma faixa de morte tranquila. Como quem leva para a terra um filho morto, levam seu próprio corpo, que baila e cintila.

Os homens gordos olham com um tédio enorme as dez bailarinas tão frias.

Pobres serpentes sem luxúria, que são crianças, durante o dia. Dez anjos anêmicos, de axilas profundas, embalsamados de melancolia.

Vão perpassando como dez múmias as bailarinas fatigadas.

Ramo de nardos inclinando flores azuis, brancas, verdes, douradas. Dez mães chorariam, se vissem 
as bailarinas de mãos dadas.

\section{Prisão}

Nesta cidade

quatro mulheres estão no cárcere.

Apenas quatro.

Uma na cela que dá para o rio, outra na cela que dá para o monte, outra na cela que dá para a igreja e a última na do cemitério ali embaixo.

Apenas quatro.

Quarenta mulheres noutra cidade, quarenta, ao menos, estão no cárcere.

Dez voltadas para as espumas, dez para a lua movediça, dez para pedras sem resposta, dez para espelhos enganosos. Em celas de ar, de água, de vidro estão presas quarenta mulheres, quarenta ao menos, naquela cidade.

Quatrocentas mulheres, quatrocentas, digo, estão presas: cem por ódio, cem por amor, cem por orgulho, cem por desprezo em celas de ferro, em celas de fogo, em celas sem ferro nem fogo, só dor e silêncio, quatrocentas mulheres, numa outra cidade, quatrocentas, digo, estão presas.

Quatro mil mulheres, no cárcere, e quatro milhões - e já nem sei a conta, em cidades que não se dizem, em lugares que ninguém sabe, estão presas, estão para sempre - sem janelas e sem esperança, umas voltadas para o presente, outras para o passado, e as outras para o futuro, e o resto - o resto, sem futuro, passado ou presente, presas em prisão giratória, presas em delírio, na sombra, presas por outros e por si mesmas, tão presas que ninguém as solta, e nem o rubro galo do sol nem a andorinha azul da lua podem levar qualquer recado à prisão por onde as mulheres se convertem em sal e muro. 
Nos dois poemas, temos a representação de um espaço de confinamento - o cassino, no primeiro, e a prisão, no segundo. E, nos dois poemas, números que remetem, cada um à sua maneira, a uma noção de totalidade. São "dez bailarinas" no primeiro poema - número lembrado em todas as estrofes, no primeiro verso, nas quatro primeiras, e no segundo verso, nas duas últimas. Há no poema uma oposição entre o elemento feminino, representado pelas bailarinas, e o elemento masculino, representado pelos frequentadores do cassino. As bailarinas são caracterizadas como "sem voz", "gafanhotos perdidos", "nuas", "frias”, “serpentes sem luxúria”, “anjos anêmicos", "múmias" de "corpos egípcios". Em contraste, o elemento masculino domina o ambiente: os "homens gordos", (em contraste com a magreza das bailarinas, reiterada várias vezes no poema) com suas "mãos sobre facas, dentes sobre flores", com seus "charutos" as olham "com um tédio enorme"; nesse ambiente, onde "escorre / uma sedosa escada de vileza”, aquelas bailarinas, cuja descrição sugere serem ainda muito jovens, quase meninas, são reduzidas a autômatos, ou a meros objetos ali postos para a distração daqueles homens; "dez mães chorariam" se vissem a condição de rebaixamento a que foram submetidas.

No poema "Prisão", o espaço de confinamento é o cárcere; na primeira estrofe seu valor é denotativo, como é também o número das mulheres presas: trata-se da cadeia, onde "quatro mulheres" estão encarceras; mas, à medida que, nas próximas estrofes, as "quatro mulheres" se tornam "quarenta", "quatrocentas", "quatro mil", "quatro milhões", o cárcere adquire um valor conotativo, passando a representar uma condição de cerceamento a que incontáveis mulheres estão submetidas. E, na medida em que se multiplica o número das mulheres, se intensifica a condição do cárcere; na segunda estrofe, são "celas de ar, de água e de vidro", voltadas "para a espuma", "para a lua movediça", "para pedras sem resposta" e "para espelhos enganosos" - a descrição parece sugerir uma representação romântica e idealizada do espaço feminino. Na terceira estrofe, porém, o espaço se reconfigura: são ou "celas de ferro", "celas de fogo", onde as mulheres estão presas "por ódio", "por amor", "por orgulho", por desprezo", ou "celas sem ferro nem fogo", mas de "dor e silêncio". Finalmente, na quarta estrofe, o cárcere é absoluto: presas "para sempre", "sem janelas e sem esperança", "sem futuro, passado ou presente", "presas por outros e por si mesmas" - o 
cárcere é tão onipresente que é introjetado pelas próprias mulheres, que "se convertem em sal e muro", como reza o último verso; a referência imediata é a personagem bíblica conhecida como 'a mulher de Ló', cujo castigo por "olhar para trás" - indo de encontro à ordem do patriarca Ló - foi ser convertida em estátua de sal, e parece sugerir a impossibilidade de escolher o próprio caminho em razão do cárcere ao qual aquelas mulheres estão submetidas.

A leitura desses dois poemas, ainda que aligeirada, é suficiente para demonstrar quanto é equívoca a afirmação de que Cecília Meireles "jamais se afirmou como mulher”. E demonstra, também, como os poemas alusivos às convulsões políticas da década de 1930, que sua poesia não está alienada do mundo, muito pelo contrário. Como a Cecília Meireles cronista, a poetisa também tem os pés fincados no chão, ainda que possa - e o faça muito frequentemente - elevar-se e "pastorear nuvens". Ler Cecília Meireles apenas pelo viés da poesia pura - ainda que ela seja uma de suas maiores cultoras - é restringir a leitura dessa poetisa, que não sem razão, se definia, como lemos no poema "Compromisso" (2001, p. 486), como a "inúmera".

\section{Referências}

ANDRADE, Mário de. Cecília e a poesia. In: ANDRADE, Mário de. O empalhador de passarinho. 3 ed. São Paulo/Brasília: Martins/INL, 1972. p. 71-76.

BLOCH, Pedro. Cecília Meireles. In: BLOCH, Pedro. Vida, pensamento e obras de grandes vultos da cultura brasileira: entrevistas. Rio de Janeiro: Bloch ed, 1989. Originalmente publicado na revista Manchete n. 630 (16/05/1964).

BOSI, Alfredo. Em torno da poesia de Cecília Meireles. In: GOUVÊA, Leila V. B. Ensaios sobre Cecília Meireles. São Paulo: Humanitas; Fapesp, 2007.

BREMOND, Henri. La poésie pure. Paris: Bernard Grasset, 1926.

CESAR, Ana Cristina. Literatura e mulher: essa palavra de luxo. In: CÉSAR, Ana Cristina. Crítica e tradução. São Paulo: Companhia das Letras, 2016.

FRIEDRICH, Hugo. Estrutura da lírica moderna: da metade do século XIX a meados do século XX. Tad. Marise M. Curione e Dora F. Da Silva. Sâo Paulo: Duas Cidades, 1978.

GOLVÊA, Leila Vilas Boas. Pensamento e "lirismo puro" na poesia de Cecília Meireles. São Paulo: Editora da Universidade de São Paulo, 2008. 
HELENA, Lúcia. Ler e reler Cecília Meireles: a escuridão e as águas de cristal. Légua \& meia: Revista de literatura e diversidade cultural. Feira de Santana: UEFS, v. 3, no 2 , 2004, p. 209-219.

LAMEGO, Valéria. A farpa na lira: Cecília Meireles na Revolução de 30. Rio de Janeiro: Record, 1996.

LISBOA, Henriqueta. Cecília Meireles. Convívio poético. Belo Horizonte: Secretaria de Educação de Minas Gerais, 1955.

MARQUES, Maria Helena Duarte. A obra de Cecília Meireles e o projeto modernista. In: Revista de Cultura Vozes. v. LXVI. Petrópolis: Vozes, 1972. p. 53-56.

MEIRELES, Cecília. Poesia completa. 2v. Rio de Janeiro: Nova Fronteira, 2001.

PIMENTEL, Brutus Abel Fratuce. O ideal poético de Paul Valéry. Anais do XII Congresso Internacional da ABRALIC (2011). Disponível em: http://www.abralic.org.br/eventos/cong2011/AnaisOnline/resumos/TC0378-1.pdf. Acessado em 10 de novembro de 2017.

SENA, Jorge de. Em louvor de Cecília Meireles. In: Estudos de cultura e literatura brasileira. Edições 70: Lisboa, 1988.

SENA, Jorge de. Cecília Meireles, ou os puros espíritos. In: Estudos de cultura e literatura brasileira. Edições 70: Lisboa, 1988.

VALÉRY, Paul. Euvres I. Paris: Gallimard, 1997. apud PIMENTEL, Brutus Abel Fratuce. O ideal poético de Paul Valéry. Anais do XII Congresso Internacional da ABRALIC (2011). Disponível em: http://www.abralic.org.br/eventos/cong2011/AnaisOnline/resumos/TC0378-1.pdf. Acessado em 10 de novembro de 2017.

Recebido em: 17/12/2020 Aceito em: 04/01/2021

\footnotetext{
1 Mesmo a autoimagem como "pastora de nuvens", no poema "Destino", é fortemente ambígua. Ao mesmo tempo em que se coloca em desvantagem aos "pastores da terra", parece haver, no poema, uma certa ironia ao caracterizar esses pastores. Estar "nas nuvens" é estar alheada do mundo, mas é, também, estar consciente da transitoriedade do mundo e estar numa posição superior, de onde se pode avistá-lo - e compreendê-lo, portanto - com mais clareza.
} 
2 Ainda em 1937, "a polícia de Getúlio Vargas faz uma devassa no Centro de Cultura Infantil do Pavilhão Mourisco, inaugurado em 1934 [por Cecília Meireles e Fernando Correia Dias, seu marido], sob a suspeita de abrigar livros comunistas [...]. A repressão getulista apreende livros [...], quebra objetos, entre os quais algumas cerâmicas de inspiração marajoara criada por Fernando Correia Dias." (GOUVEIA, 2001, p. 80). Getúlio Vargas ordena o fechamento do Centro, pondo fim a um inovador projeto de educação infantil idealizado, criado e dirigido por Cecília Meireles. 